\title{
ANALISIS SISTEM DAN PROSEDUR PENGADAAN BARANG DAN JASA DI KOMISI PEMILIHAN UMUM PROVINSI SULAWESI UTARA
}

\author{
Ester Lita Juniani Majampoh ${ }^{1}$, David P.E. Saerang ${ }^{2}$, Dhullo Afandi ${ }^{3}$ \\ ${ }^{1,2,3}$ Jurusan Akuntansi, Fakultas Ekonomi dan Bisnis, Universitas Sam Ratulangi, Jl. Kampus Bahu, Manado, \\ 95115, Indonesia
}

E-mail : ester.majampoh@yahoo.com

\begin{abstract}
Goods and services procurement by the government is an important activity in national development to increase public services and economic development. As a government institution, the General Election Committee must be able to account the goods and services procurement in the aspects of administration, technical, and finance. The research purpose is to analyze whether the goods and services procurement in the North Celebes Province General Election Committee is adequate or not. In this research are the explanation about local goods planning procedure and local goods procurement procedure in the North Celebes Province General Election Committee. The procedures are then analyzed by the internal control analysis from COSO and compliance analysis.
\end{abstract}

Keywords : Planning, Procurement, sequacity.

\section{PENDAHULUAN}

Pengadaan barang dan jasa pemerintah atau "Pengadaan Langsung". Peraturan Presiden mengamanatkan pelaksanaan pengadaan langsung untuk barang dan jasa lainnya tidak harus dilakukan proses untuk prakualifikasi. Dengan demikian dalam pengadaan langsung persyaratan kualifikasi penyedia tidak harus terpenuhi. Dalam kenyataannya masih banyak Pejabat Pengadaan yang lebih mementingkan terpenuhinya persyaratan kualifikasi ketimbang efisiensi harga. Dengan mempertimbangan terpenuhinya syarat-syarat kualifikasi, mereka lebih suka menunjuk penyedia berbentuk badan usaha dari pada penyedia perseorangan walaupun harga penawaran dari badan usaha lebih mahal dibandingkan penyedia perseorangan. Adapun proses pengadaan barang dan jasa pemerintah adalah kegiatan untuk memperoleh Barang/Jasa oleh Kementrian/Lembaga/Satuan Kerja Perangkat Daerah/Institusi lainnya yang prosesnya dimulai dari perencanaan kebutuhan sampai diselesaikannya seluruh kegiatan untuk memperoleh barang/jasa. Dalam pengadaan barang/jasa harus mempunyai sistem yang baik untuk mendukung seluruh kegiatan produksi yang dilakukan perusahaan.

Setiap pengadaan barang/jasa tersebut juga harus terdapat pengendalian intern untuk mengarahkan, mengawasi dan mengukur sumberdaya suatu organisasi serta mencegah dan menemukan ketidaksesuain prosedur. Pengadaan bertujuan untuk mendapatkan barang atau benda. Untuk itu dalam setiap perusahaan baik itu swasta maupun pemerintah hendaknya memiliki sistem dan prosedur dasar pelaksanaan kerja untuk menunjang kelancaran operasi perusahaan. Dengan adanya sistem dan prosedur yang memadai maka pengendalian dan tujuan yang akan dicapai dalam suatu organisasi dapat berjalan dengan baik.

\section{TINJAUAN PUSTAKA}

Tujuan Utama Sistem Informasi Akuntansi. Menurut Krismiaji (2012), terdapat dua tujuan utama sistem informasi akuntansi yaitu: (1) menentukan apakah informasi yang dihasilkan bisa dipercaya; dan (2) menentukan segala aktivitas suatu bisnis sesuai dengan tujuan dan peraturan yang ditetapkan. 
Akuntansi Pemerintahan. Menurut Putera (2015), Akuntansi Pemerintahan adalah aktivitas yang mengkhususkan diri pada pencatatan dan pelaporan pada badan keuangan pemerintahan.

Prosedur Pengadaan Barang dan Jasa. Prosedur pengadaan barang dan jasa merupakan suatu rangkaian susunan pengendalian atau pengawasan kegiatan barang dan jasa.

Pengendalian Internal Menurut COSO. Menurut Wahyunidewi (2017), Pengendalian internal adalah suatu pembagian penting untuk mencapai tujuan perusahaan.

\section{METODE PENELITIAN} deskriptif.

Jenis Penelitian. Penelitian ini bersifat kualitatif dengan pendekatan analisis

Tempat dan Waktu Penelitian. Penelitian dilakukan pada Kantor Komisi Pemilihan Umum Provinsi Sulawesi Utara. Waktu penelitian yaitu bulan April 2018 sampai dengan Agustus 2018.

\section{Jenis, Sumber, dan Metode Pengumpulan Data}

Jenis Data. Data kualitatif dalam penelitian ini berupa penjelasaan dari staf Komisi Pemilihan Umum mengenai prosedur pembayaran pengadaan barang dan jasa.

Sumber Data. Sumber data dalam penelitian ini yakni sumber data primer yang diperoleh langsung dari objek penelitian, berupa data prosedur pengadaan barang dan jasa serta penjelasan dari staf Komisi Pemilihan Umum mengenai prosedur pengadaan barang dan jasa.

Metode Pengumpulan Data. Metode pada pengumpulan data dalam penelitian ini yakni: (1) wawancara; (2) observasi; dan (3) dokumentasi.

Metode dan Proses Analisis. Metode dan proses analisis yang digunakan dalam penelitian ini adalah analisis deksriptif. Melalui hasil penelitian, dilakukan analisis kepatuhan dan analisis aspek-aspek pengendalian internal menurut COSO. Kemudian dibahas bersama dengan teori dan penelitian terdahulu.

\section{HASIL PENELITIAN DAN PEMBAHASAN}

\subsection{Hasil Penelitian}

Prosedur Perencanaan Kebutuhan Barang Milik Daerah di Komisi Pemilihan Umum Provinsi Sulawesi Utara. Prosedur Perencanaan dimulai dengan penyusunan rencana kerja tingkat pusat oleh KPU RI, kemudian KPU Provinsi/Kabupaten kota menyusun rencana kerja dan anggaran untuk selanjutnya dilakukan rapat kerja nasional untuk sinkronisasi program kerja dan anggaran pada masing-masing satker. Hal ini dilakukan untuk 1 tahun anggaran. Setelah adanya rancangan umum pengadaan (RUP) dan rancangan anggaran belanja (RUB) kemudian (PPK pejabat pembuat komitmen) menyusun paket pengadaan barang dan jasa termasuk spesifikasi barang, jumlah jangka waktu pelaksanaan sumber anggaran penerima pekerjaan, semua itu dirangkum dalam bentuk Kerangka Acuan Kegiatan (KAK) dan Pejabat Pembuat Komitmen (PPK) memerintahkan kepada unit layanan pengadaan (ULP) untuk melakukan proses pengadaan barang dan jasa tersebut.

Prosedur Pengadaan Barang dan Jasa di KPU Provinsi. Pengguna anggaran atau pejabat pemegang kewenangan penggunaan anggaran menyerahkan RUP dan KAK kepada PPK, dan PPK menyusun Harga Perkiraan Sendiri sebagai bukti untuk perjanjian. Rancangan Surat Perintah Kerja diberitahukan pada Pejabat Pengadaan untuk dilakukan proses Pengadaan Langsung Di KPU Provinsi Sulawesi Utara sesuai dengan SDP (Standar Dokumen Pengadaan). Pengadaan barang/jasa di lingkungan KPU Provinsi Sulawesi Utara pada prinsipnya mengacu pada peraturan Pengadaan Barang/Jasa Pemerintah dan disesuaikan dengan kebutuhan dan ketersediaan anggaran tahun bersangkutan. Oleh karena itu pengadaan 
dilakukan oleh Pejabat Pengadaan Barang/Jasa. Berikut ini adalah dokumen Barang dan Jasa di Lingkungan KPU yang diadakan pada Tahun Anggaran 2017 tanggal 1 november yaitu :

1. 3 unit Komputer (PC)

2. 4 unit Laptop

3. 3 unit Printer

4. 5 unit Kamera Digital DLSR

5. 1 unit Scanner

6. 2 unit Handycam

\subsection{Pembahasan}

\section{Analisis Perencanaan Kebutuhan Barang Milik Daerah}

Analisis Kepatuhan Perencanaan Kebutuhan Barang Milik Daerah. Berdasarkan hasil penelitian dapat dikatakan bahwa perencanaan kebutuhan barang milik daerah yang dilaksanakan oleh Komisi Pemilihan umum telah dilaksanakan sesuai dengan peraturan ini dinyatakan bahwa perencanaan kebutuhan BMD dilaksanakan berdasarkan prinsip-prinsip efektif, efisien, terbuka dan transparant, adil/tidak diskriminati dan akuntabel, dibuktikan dengan perencanaan yang dilaksanakan Komisi Pemilihan Umum dan Provinsi Sulawesi Utara.

Analisis Pengendalian Internal COSO Perencanaan Barang Milik Daerah Komisi Pemilihan Umum. Ditinjau dari aspek pengendalian internal menurut COSO, hasil analisis peneliti untuk proses pengadaan barang/jasa yaitu:

1. Lingkungan Pengendalian (Control Invironment). Lingkungan pengendalian di Lingkungan Komisi Pemilihan Umum Provinsi sudah memadai, dibuktikan dengan adanya PLT.

2. Penilaian Risiko (Risk Assessment). Penilaian risiko terhadap prosedur perencanaan kebutuhan barang milik daerah yang di lakukan oleh Komisi Pemilihan Umum di mulai dari proses dari Barang Milik Daerah di Komisi Pemilihan Umum Sulawesi Utara yaitu setelah adanya rancangan umum pengadaan (RUP) dan rancangan umum belanja (RUB) sehingga bisa di analisa kemungkinan-kemungkinan resiko yang akan terjadi seperti risiko mengenai lebihnya dana yang akan dikeluarkan dan lain-lain.

3. Aktivitas Pengendalian (Control Activities). Aktivitas pengendalian dalam perencanaan barang milik daerah di Lingkungan Komisi Pemilihan Umum sudah memadai, dibuktikan dengan adanya otorisasi, verifikasi seperti adanya tanda terima yang ditanda tangani langsung oleh Kepala Bagian Keuangan Umum dan Logistik.

4. Informasi dan Komunikasi (Information And Communication). Program atau kegiatan di Komisi Pemilihan Umum Provinsi Sulawesi Utara akan sangat baik apabila pihak yang terlibat dapat berkomunikasi serta memberikan informasi dengan baik. Lembaga Kebijakan Pengadaan Barang/Jasa Pemerintah (LKPP) khususnya Direktorat Perencanaan, Evaluasi dan Monitoring Pengadaan mengembangkan Aplikasi Sistem Informasi Rencana Pengadaan (SIRUP) secara online yang dapat diakses melalui website www.sirup.lkpp.go.id sebagai alat informasi yang memudahkan Pengguna Anggran dalam mengumumkan Rancangan Umum Pengadaan (RUP) secara akurat, transparan dan akuntabel.

5. Aktivitas Pemantauan (Monitoring Activities). Kegiatan pemantauan ini bertujuan untuk memantau atau mengawasi setiap pergerakan dari setiap kegiatan/program yang sudah disusun dalam Sistem Informasi Rancangan Umum Pengadaan (SIRUP) dari waktu ke waktu. 


\section{Analisis Pengadaan Barang dan Jasa pada Komisi Pemilihan Umum Provinsi Sulawesi Utara}

Analisis Kepatuhan Pengadaan Barang dan Jasa di KPU Provinsi. Berdasarkan hasil penelitian yang ada bahwa pengadaan barang dan jasa di KPU telah sesuai dengan peraturan yang ada, dibuktikan dalam Peraturan Presiden No. 54 Tahun 2010 dalam Pasal 4 ayat (1).

Analisis Pengendalian Internal COSO Pengadaan Barang dan Jasa. Ditinjau dari aspekaspek pengendalian internal menurut COSO, hasil analisa peneliti untuk Perencanaan Barang Milik Daerah di KPU Provinsi maupun Kabupaten/Kota se Sulawesi Utara yaitu :

1. Lingkungan Pengendalian (Control Invironment). Lingkungan pengendalian dalam pengadaan barang dan jasa di Lingkungan Komisi Pemilihan Umum Provinsi Sulawesi Utara sudah memadai, dibuktikan dengan adanya aturan yang mengatur yang tertuang dalam Peraturan Presiden 54 Tahun 2010, adanya struktur organisasi yang terdiri dari PLT.

2. Penilaian Risiko (Risk Assessment). Penilaian risiko dalam pengadaan barang dan jasa didalamnya terdapat masalah dalam kurangnya pemahaman dari pegawai dan pihak penyedia barang dan jasa atau rekanan mengenai pengadaan barang dan jasa melalui proses penunjukkan langsung.

3. Aktivitas Pengendalian (Control Activities). Kegiatan ini diterapkan di Komisi Pemilihan Umum Provinsi Sulawesi Utara yaitu dilakukan review atas kinerja yang dilakukan oleh pegawai dengan membandingkan kinerja setiap tahun dengan tolak ukur kinerja yang sudah ditetapkan.

4. Informasi dan Komunikasi (Information And Communication). Proses perencanaan barang milik daerah sudah memadai di buktikan dengan prosesnya yang sekaligus mengumpulkan, menganalisa, mengklasifikasi.

5. Aktivitas Pemantauan (Monitoring Activities). Menurut informasi yang didapatkan peneliti dari wawancara dengan Bapak Rudy Lalonsang bahwa aktivitas pemantauan sudah memadai, dibuktikan dengan adanya pengawasan dari pihak Kementerian/Lembaga/Pemerintah/Daerah/Institusi, yang merupakan bagian dalam metode barang milik daerah.

\section{KESIMPULAN DAN SARAN}

\subsection{Kesimpulan}

Berdasarkan pembahasan yang dilakukan penulis dalam menganalisis sistem dan prosedur pengadaan barang dan jasa, dapat ditarik kesimpulan sebagai berikut :

1. Perencanaan kebutuhan Barang Milik Daerah yang dilaksanakan oleh Komisi Pemilihan Umum di Provinsi Sulawesi Utara telah dilaksanakan dengan peraturan yang ada, dan telah berlandaskan pada Peraturan Pemerintah Nomor 27 Tahun 2014 pasal 12 ayat (1).

2. Pengadaan barang dan jasa yang dilakukan oleh KPU Sulawesi Utara pada prosesnya berkaitan dengan prosedur telah dilaksanakan sesuai dengan peraturan yang mengacu pada PP No. 54 Tahun 2010 yaitu pembuatan Rincian Kebutuhan Barang/Jasa, setelah dikeluarkannya Rincian Kebutuhan Barang/Jasa baik untuk kebutuhan Rutin maupun Pemilu, maka proses pengadaannya dilakukan dengan mengacu pada Perpres 54 Tahun 2010 berserta perubahannya, sehingga setelah Petugas SIRUP langsung menginput ke aplikasi pengadaan setelah menerima RKA-KL tahun berjalan, setelah itu diumumkan. Dalam rincian tersebut telah dipilah barang/jasa yang diadakan secara langsung dan diadakan lewat mekanisme Lelang maupun Swakelola.

3. Ditinjau dari aspek pengendalian internal menurut COSO, hasil analisa Peneliti untuk perencanaan dan proses pengadaan Barang/Jasa di Lingkungan KPU Provinsi sudah memadai. 


\subsection{Saran.}

Berdasakan hasil yang dilakukan dalam menganalisis sistem dan prosedur pengadaan barang dan jasa, selain adanya pengadaan barang dan jasa, pihak pengguna diharapkan mempergunakan barang/jasa yang telah disediakan dengan sebaik mungkin. Untuk itu diperlukan edukasi atau pelatihan-pelatihan kepada pegawai pihak penyedia barang dan jasa Komisi Pemilihan Umum Provinsi Sulawesi Utara.

\section{DAFTAR PUSTAKA}

Azhar, Susanto. 2013. Pengertian sistem dan informasi menurut para ahli http://www.pengertianmenurutparaahli.net-pengertian-informasi-menurut-para-ahlidan-tahunnya.html

Dony. 2017. Pengertian standar akuntansi pemerintahan dan peraturannya http://rocketmanajemen.com/standar-akuntansi-pemerintahan.

Ervianto. 2015. Pengadaan barang dan jasa pemerintah menurut para ahli https://www.google.com.pengadaan-barang-dan-jasa-pemerintah.html

Mulyadi. 2016. Pengertian sistem prosedur pengadaan barang dan jasa https://www.google.com/karakteristikprosedurmenurutmulyadikarakteristikprosedur.h tml

Peraturan Presiden Nomor 54 Tahun 2015 tentang Pengadaan Barang dan Jasa Bersumber dari Anggaran Pendapatan Belanja Daerah (APBD) dan Anggaran Pendapatan Belanja Negara (APBN)

Putera. 2015. http://puterarantau.blogspot.com/2015/03/akuntansi-pemerintahan.html

Suryani. 2016. Standar Akuntansi Pemerintahan dan pengertian serta pemahamannya dan contoh http://.blogspot.com/2013/06/standar-akuntansi-pemerintahan.html

Sumangkut, Roy. Y. A. 2014. Analisis Akuntabilitas Sistem Pengadaan Secara Elektronik v.3.5 Dalam Proses E-Tendering. Program Pascasarjana Prodi Teknik Universitas Sam Ratulangi. Manado.

Sailendra. 2017. pengertian Standar operasional prosedur dan manfaatnya serta cara dan contoh https://www.jurnal.blog/2017/manfaat-cara-dan-contoh-sop.html

Tanesia, K. R. 2015. Studi Efektivitas Penggadaan Barang dan Jasa Pemerintah Secara Tradisional dan Elektronik. Program Pascasarjana Universitas Atma Jaya. Yogyakarta.

Wiratna, S., 2015. Akuntansi Sektor Publik. Penerbit Pustaka Baru Press: Yogyakarta.

Yeri, Adriyanto. 2015. Pengadaan langsung dan metode langsung serta pengadaan barang dan jasa pemerintah.http://axellelessons.blogspot.co.id.barang-dan-jasa-pemerintah.html 